\title{
Using Audiobooks for Developing Listening Comprehension among Saudi EFL Preparatory Year Students
}

\author{
Manal Mohamed Khodary Mohamed \\ Ismailia Faculty of Education, Suez Canal University, Egypt
}

\begin{abstract}
The current study investigated the usefulness of using audiobooks on developing listening comprehension among Saudi English as a Foreign Language (EFL) preparatory year students. It employed the quasi-experimental design which included two groups: an experimental group $(n=44)$ and a control group $(n$ = 44). The participants were EFL preparatory year students at Arar Branch, Northern Border University, Kingdom of Saudi Arabia. Before conducting the treatment, the experimental group and the control group were pre-tested by using the pre Listening Comprehension Test (LCT) for equivalence of listening comprehension. By the end of the treatment, the experimental group and the control group were post-tested by using the post LCT. The t-test was used to calculate the differences between the mean scores of the pre and post LCT. The results showed that a statistically significant difference between the mean scores of the experimental group and the control group on the post LCT in favor of the experimental group. The results also revealed that a statistically significant difference was found in the mean scores of the experimental group between the pre and post LCT in favor of the post LCT. Thus, it can be concluded that the audiobooks helped the experimental group develop listening comprehension as they exceeded the control group on the post LCT and they achieved a better result on the post LCT than the pre LCT.
\end{abstract}

Index Terms—audiobooks, listening comprehension, Saudi EFL preparatory year students

\section{INTRODUCTION}

Listening is considered the most important language skill for achieving effective communication and good academic achievement among learners. It is a highly integrative skill because it is generally the first skill which learners develop (Oxford, 1993; Vandergrift, 1999). It has been emphasized as an essential component in the Second Language Acquisition (SLA) process (Vandergrift, 2003). It has a great role in the construction of language abilities of a Foreign Language (FL) learner (Rost, 2002). It has acknowledged a great importance in FL classrooms (Richards \& Renandya, 2002; Rahimi, 2012). The role and importance of listening in SLA exceeds acquiring meaning from sounds because it does not only mean recognizing the sounds but it also involves detecting, conveying and comprehending the information and it allows comprehending the world and creating social relationships among humans (White, 2006). In spite of the importance of listening, it did not get concern in language teaching for many years (Richards \& Renandya, 2002; Nation \& Newton, 2009). It was the least understood and the most overlooked of the four skills (Nation \& Newton, 2009; Wilson, 2008). Moreover, listening is the most difficult task for learners when they begin to learn a FL and it is the most challenging skill to be developed (Berne, 2004; Vandergrift, 2007).

Listening comprehension is a complex dynamic process in which a listener has to distinguish sounds, comprehend vocabulary, understand grammatical structure, infer stress and intonation and relate them into the context (Vandergrift, 1999). It denotes the ability of a listener to comprehend a text read aloud or narrated on an audio recording which she/he listens to (Kintsch \& Kintsch, 2005). Though it is necessary to develop listening comprehension among language learners, they were seldom taught how to listen effectively (Vandergrift, 2007). Moreover, listening comprehension has received the least attention in language teaching, learning, research and assessment although it is considered the most essential skill in a language (Oxford, 1993; Mendelsohn, 2001; Clement, 2007; Gilakjani \& Ahmadi, 2011). Finding good techniques and strategies for teaching listening comprehension has been emphasized in research conducted by some researchers (e.g. Graham, 2006; Vandergrift, 2007).

The researcher worked as an associate professor at Northern Border University (NBU) in Kingdom of Saudi Arabia (KSA) and she taught English Language course to EFL preparatory year students at Arar Branch. The researcher realized that most of her preparatory year students had weaknesses in listening comprehension. Besides, the instructors at this university complained of the weaknesses in listening comprehension among their preparatory year students. The listening comprehension weaknesses among EFL preparatory year students were revealed in their inability to comprehend the information which they listened to through listening to any materials of any type such as listening to the English news on the radio and the TV or during watching an English film on a video because they could only remember the first sentence of the listening material and missed remembering the rest of the material. They could not also express the information which they listened to in written and oral forms. 
In order to investigate the existence of the listening comprehension problem among EFL preparatory year students at NBU, the researcher checked their scores on previous listening comprehension exams and found that their scores on these exams were very low compared with their scores on other EFL skills exams. Then, the researcher interviewed 19 preparatory year students at NBU on the weaknesses in listening comprehension they had. They pointed out that to them listening did not receive a considerable attention from their EFL instructors who neglected teaching listening comprehension to them since they did not receive practice on proper activities for doing listening comprehension. They indicated that their weaknesses in listening comprehension could be a result of the unsuitable strategies for teaching listening comprehension provided to them by their EFL instructors. They also revealed that although they were provided with listening materials such as CDs, audio cassettes and books that included questions to be used for practicing listening and which might support the teaching of listening comprehension, they had weaknesses in listening comprehension.

The researcher conducted an interview with $5 \mathrm{EFL}$ instructors at the preparatory unit at NBU to investigate the existence of the listening comprehension problem among their EFL preparatory year students. The instructors indicated that although their EFL preparatory year students were exposed to spoken English and to listening to materials of various types, they failed to understand most of the information which they had listened to and they were not capable of developing listening comprehension. They pointed out that their students suffer from weaknesses in listening comprehension because no effective listening strategies nor suitable listening activities were given to them to help them develop listening comprehension. Thus, they thought that it is necessary to determine good techniques and effective strategies for teaching audio input to EFL preparatory year students to help them develop listening comprehension. They also revealed that their students had listening comprehension weaknesses although they were provided with appropriate English Language labs supplied with computers and listening materials of various types to support practicing of listening comprehension. The researcher reviewed previous studies conducted on the problem of listening comprehension among Saudi university students. She realized from her review that studies carried out by Alotaibi (2014), Batel (2014) and Hamdan (2015) were done because Saudi university students suffered from weaknesses in listening comprehension.

\section{A. Statement of the Problem}

The pilot studies done on investigating EFL preparatory year students' problem with listening comprehension showed that they suffered from weaknesses in listening comprehension. In order to find a solution for this problem, the researcher conducted the current study to reveal whether audiobooks could improve listening comprehension among EFL preparatory year students.

\section{B. Hypotheses}

1. There would be a statistically significant difference $(\mathrm{p}<0.05)$ between the mean scores of the experimental group and the control group on the post Listening Comprehension Test (LCT) in favor of the experimental group.

2. There would be a statistically significant difference $(p<0.05)$ in the mean scores of the experimental group between the pre and post LCT in favor of the post LCT.

\section{Aim}

The aim of the current study was to explore the usefulness of audiobooks on enhancing EFL preparatory year students' listening comprehension.

\section{Significance of the Study}

The results of the current study could be vital to EFL preparatory year students because they might give them a new methodology represented in using audiobooks in listening and repeated listening while reading a printed version of the listening text in order to develop their listening comprehension. They might also be significant to EFL instructors because they could offer them an effective tool represented in audiobooks to be used in teaching listening to EFL preparatory year students so as to help them improve listening comprehension. Furthermore, the results could be significant to curriculum developers as they might reveal to them the usefulness of audiobooks in developing listening comprehension among EFL preparatory year students and thus they showed them the importance of designing suitable audiobooks for students to practice listening and develop listening comprehension.

\section{E. Delimitations of the Study}

1. This study was carried out at the preparatory year unit, Arar Branch, NBU, KSA because the researcher worked at this university.

2. EFL preparatory year students at Arar because the researcher taught them English Language course.

3.A limited duration for conducting the treatment (10 weeks, 3 hours for each week) as requisite to train the experimental group on using audiobooks to help them develop listening comprehension.

\section{F. Variables}

In the current study, the independent variable was audiobooks whereas the dependent variable was EFL preparatory 
year students' listening comprehension.

\section{G. Definitions of Terms}

1. Audiobooks: The researcher operationally defined audiobooks as a printed book's audio recorded versions of the narration which a user listens to as well as does repeated listening while reading the printed copy of the book.

2. Listening comprehension: The researcher operationally defined listening comprehension as an active process through which listeners connect the information that they listen to with their prior knowledge and information of the aural input while applying various strategies and techniques to comprehend the listened material.

\section{THEORETICAL FRAMEWORK}

\section{A. History of Audiobooks}

Audiobooks were previously referred to under the term "talking book". Talking books were first presented around the 1931s and they were implemented by the American government to be used as "Books for the Adult Blind Project" introduced for free to help the blind readers. The term "audiobook" appeared in 1970s with the demand of audiocassettes (Rubery, 2011). Audiobooks went through several developments. The first recordings of the talking books appeared in 1934 and involved sonnets by Shakespeare and short stories by Hasty and they were followed by a recording called Learning Ally which Macdonald founded in 1948. Several companies were established in 1952 with the purpose of making and selling spoken recordings which were in the form of poems, plays and short texts. Other companies such as Listening Library were founded in 1955 in order to distribute children's spoken recordings to libraries and schools. Cassette tapes were invented in 1963 and a wide spread in making them occurred since 1970s and they were followed by technological innovations such as videos. CDs replaced cassette tapes and they were widely used from 2003. The advent of the Internet helped in the prevalence of the downloads of audiobooks from 1990 and they became available to be easily downloaded at any time (Rubery, 2011).

Audiobooks are recently considered as a dominant literacy tool and as one of the most essential resources in the FL learning process because they might help construct language skills among learners (Serafini, 2004). They have been regarded as a scaffold tool used for enhancing literacy among users (Blum, Koskinen, Tennant, Parker, Straub, \& Curry, 1995; Jacobs, 2006; Hett, 2012). The use of audiobooks has spread since they were implemented in classrooms to develop reading comprehension among kids and struggling readers (Koskinen, Blum, Bisson, Philips, Creamer, \& Baker, 2000; Harris, 2001; O’Day, 2002; Stone-Harris, 2008). They have been widely used in all stages of education (Beers, 1998; Wolfson, 2008). Most previous studies on using audiobooks were carried out on young learners (Kartal \& Şimşek, 2011). Previous studies on using audiobooks with university students primarily focused on their effects on their reading comprehension and learning of vocabulary (Marchionda, 2001; Woodal, 2010; Thooft, 2011).

\section{B. General Advantages of Implementing Audiobooks in Language Learning}

There are numerous general advantages of implementing audiobooks in language classes. One of the general advantages is providing a learner with a chance to learn new vocabulary because she/he encounters to new words when she/he reads and listens to a text and therefore these new words become part of her/his oral and written vocabulary (Serafini, 2004). Another advantage of audiobooks encompasses of helping learners learn the pronunciation of words which they listen to delivered in appropriate intonation and pronunciation and which they see in print (Saka, 2015; Tagninezhad, Khalifah, Nabizadeh, Shahab, 2015). Moreover, audiobooks can provide learners with opportunities to increase active listening, enhance listening skills and develop reading skills, writing skills and critical thinking skills (Jakobs, 2006;Türker, 2010; Kartal \& Şimşek, 2011).

Advantages of audiobooks also involve giving learners a chance to enhance their level of independent reading and to read fluently because they give them models of fluent reading for the material which they listen to (O'Day, 2002; Nalder \& Elley, 2003). Moreover, audiobooks can provide learners with the opportunity to discuss the stories which they listened to and read and thus they might develop reading comprehension among learners because they help them focus on meaning (Serafini, 2004; Wolfson, 2008). They might also enable learners to comprehend different types of texts above their reading level, analyze, comprehend and enjoy and like more complex literature (Beers, 1998; Kartal \& Şimşek, 2011). And, they were regarded as valuable tools which might solve struggling readers' problem with reading because they learn to match the sounds of oral language with their written equivalents during listening (Jakobs, 2006; Türker, 2010; Kartal \& Şimşek, 2011).

\section{Related Literature}

Listening is a fundamental skill which is related to the ability of comprehension (Berne, 1995; Graham, 2006). Research on listening in the field of EFL during the early decades focused on checking abilities of learners to listen to oral discourse and then answer comprehension questions based on the provided knowledge, without giving them instructions on applying strategies for accomplishing such tasks (Field, 1998). The teaching of listening by using textbooks was a neglected area until the 1970s. It was supposed that learners could develop listening through practice when they are exposed to an oral discourse through repetition and imitation and they might improve it naturally while learning a FL (Getahchew, 2002; Clement, 2007). Listening comprehension is regarded as an active process through 
which humans form meaning from passages and link the information which they listen with existing knowledge (Gilakjani \& Ahmadi, 2011). For EFL learners' development in learning a FL, mastery of listening comprehension is the first step towards fully acquiring a FL (Liu, 2009). Thus, it is necessary to discover and use suitable techniques and useful strategies for teaching listening comprehension to help learners develop it (Graham, 2006; Vandergrift, 2007; Rahimi, 2012). To make listening comprehension effective, activities can be done through listening while reading, repeated listening, interactive listening and non-linguistic or semi-linguistic support (Elkhafaifi, 2005; Kao, 2006; Nation \& Newton, 2009).

Due to the utility of audiobooks in language learning, their effectiveness for enhancing language learning regarding developing pronunciation, writing, reading, and grammar has been investigated by numerous studies. Examples of these studies were the following: (O'Day, 2002; Nalder \& Elley, 2003; Brown \& Fisher, 2006; Türker, 2010). Most previous studies based mainly on investigating the effect of audiobooks on students' reading skill (Taguchi, Takayasu-Maass, \& Gorsuch, 2004; Golonka, Bowles, Frank, Richardson, \& Freynik, 2014). Little research was carried out to explore the usefulness of using audiobooks on developing listening comprehension among university students. It is worth mentioning that most studies on the effects of audiobooks on students' listening skills were based on using classroom observations and qualitative data (Shany \& Biemiller, 1995; Hamdan, 2015). Moreover, the researcher did not find any study that was conducted with the aim of exploring the effects of using audiobooks on developing listening comprehension among EFL university students at the Saudi context.

\section{METHOD}

\section{A. Research Design}

It was a pre, posttest quasi experimental study which comprised of 2 groups: an experimental group and a control group. The researcher pre tested the 2 groups by using the pre LCT for equivalence in their listening comprehension prior to the treatment of the current study. By the end of conducting the treatment, she post tested the 2 groups by using the post LCT to assess their listening comprehension. She used the t-test to calculate the difference between the mean scores of the pre LCT and the post LCT.

\section{B. Participants}

The participants were EFL preparatory year female students who ranged from 18 to 20 years old. They formed 2 classes which the researcher randomly chosen from her list of classes that studied English Language course during that academic semester at Arar Branch, NBU. EFL preparatory year students at NBU were already randomly assigned into classes by their university. They had a similar linguistic background of EFL because they had studied it for about 10 years. They were all Saudis who were born of Saudi parents and they lived and raised in KSA. They were supposed to join faculty of education and arts by the end of their preparatory year and after they pass all of their courses. Their EFL instructors were Saudi native speakers of Arabic with the same teaching experience with university students. The English Language course provided to the participants comprised of teaching them grammar, listening, speaking, reading and writing. The participants used to receive one listening session which lasted for 3 hours once every week. They practiced listening through listening to materials of various types such as audio cassettes, videos, oral conversations, and CDs followed by oral comprehension questions without having the opportunity to read from printed versions of the texts which they listened to. They had no previous experience with using the audiobooks of the current study in practicing listening inside and outside of their classes prior to the treatment. Moreover, they did not have any experience with studying the texts of the stories of the audiobooks of the current study because they did not read them and they did not listen to them before the application of the treatment. The researcher was responsible of teaching listening to the participants throughout the current study.

The researcher used the pre LCT to reveal whether the experimental group and the control group were equivalent in listening comprehension before conducting the study. Then, she used the t-test to test the significance between the two groups on the pre LCT. The result indicated that the difference in the mean scores between the experimental group and the control group on the pre LCT was not statistically significant $(t=0.717, \mathrm{p}>0.05)$. This result meant that the 2 groups were equivalent in listening comprehension preceding to the treatment. This result is presented in Table (1).

TABLE 1

THE T-VALUE OF THE DIFFERENCE IN THE MEAN SCORES BETWEEN THE EXPERIMENTAL GROUP AND THE CONTROL GROUP ON THE PRE LCT

\begin{tabular}{l|l|l|l|l|l|l}
\hline Group & N & Mean & SD & DF & T & Sig. \\
\cline { 1 - 4 } Experimental & 44 & 10.59 & 2.08 & \multirow{2}{*}{86} & \multirow{2}{*}{0.717} & 0.475 \\
\hline Control & 44 & 10.93 & 2.36 & & \\
\hline
\end{tabular}

\section{Instrument}

\section{The LCT (See the Appendix)}

The researcher designed the LCT by adopting conversations and lectures from a book entitled "Prepare and Practice for the Computer-Based TOEFL Test" which was written by Taylor and Moore and was published in 2001. The researcher depended on the listening lessons given to EFL preparatory year students at NBU in their English Language 
course as a basis to choose the listening texts in order to make the LCT valid for the participants of the current study regarding its level of vocabulary and grammatical structure. The LCT consisted of 6 parts which encompassed of classroom discussions, parts of lectures, parts of talks and a telephone conversation. Each part was followed by four Multiple Choice Questions (MCQs) with four options in each question. The topics of the LCT were different from the topics of the audiobooks which the researcher used in the current study. The directions of the LCT were introduced in a separate section at the beginning. The questions and the directions of the LCT were written in English and they were clear, simple and brief. The audio recorder of the LCT was made in a clear and good voice which was delivered at suitable speed with natural delivery to be audible to all the participants. The questions of the LCT were made in a printed version to be given to the participants to use and answer questions on it. Only one option in each question was correct. The researcher assigned one mark for each correct answer given by a participant on the LCT.

To validate the LCT regarding whether this test and its directions were comprehensible, readable and suitable for the participants of the current study, the researcher provided it to a jury of 7 EFL instructors who taught English Language to EFL preparatory year students at some universities in the KSA. The jury pointed out that the texts, the questions and the directions of the LCT included suitable vocabulary for the participants' linguistic level and they knew the meaning of all the provided vocabulary. They added that the grammatical level of the LCT was also suitable for the linguistic level of the participants and hence it might be comprehensible to them. Moreover, they indicated that the audio recording of the LCT was audible and perfect and they revealed that the pronunciation of the speakers on the LCT was clear with a proper speed and careful pauses. Hence, the jury members assured the LCT's validity for the participants in the current study because of its comprehensible texts, readable questions, clear directions and audible recordings.

The researcher also provided the LCT to a pilot sample of 19 EFL preparatory year students who did not take part in the current study to reveal the validity of this test and the validity of its directions for the current study. The pilot sample assured that the LCT and the directions were comprehensible to them because they knew the meaning of all the vocabulary provided in them and as they found that its grammatical level was suitable for them. They indicated that the topics of the selected texts in the LCT were familiar for them because they knew the meaning of the included vocabulary. They also revealed that the audio recording of the LCT was clear and audible and the pronunciation , speed and pauses of the speakers on the recording are good. The researcher estimated the timing of the LCT by the same piloting and found that it was 60 minutes.

The reliability of the LCT was assessed as the researcher used the test / retest method with it and she applied it on a pilot sample of 21 EFL preparatory year students who were not among the current study's participants and she applied it again on the same pilot sample after a period of 15 days span. She used Pearson's coefficient of correlation between the first and the second administrations of the LCT. The result was 0.85 and it showed that the LCT achieved a high degree of reliability.

\section{Materials}

\section{- Selected Audiobooks for the Application of the Listening Sessions}

The researcher selected the audiobooks from the Internet. They were made in a form of short stories enclosed in a book entitled "Half-Past Seven Stories". This book was composed by Robert Gordon Anderson in 1922. It represented a continuation of the Seven O'Clock Stories, followed the adventures of Marmaduke and the Toyman. These audiobooks were intended to be used in the listening sessions of the current study as the researcher would permit the experimental group to listen and repeat listening while reading printed versions of them. The audiobooks were both narrated by native American speakers of English. The texts of the audiobooks were made in printed versions and were intended to be used by the experimental group for reading during the listening and the repeated listening to the audio recordings. One of the bases of selecting these audiobooks was their length which was reasonable for in class listening and reading. The familiarity of the vocabulary of the texts of the audiobooks for the participants was also another basis for selecting them. The audiobooks were suitable for the linguistic level of the participants regarding their vocabulary, grammar and the pronunciation of their speakers. Besides, PDF versions of the audiobooks were available on the Internet to be easily downloaded on computers and printed at any time.

The researcher checked the validity of the audiobooks by providing them to the jury members to give their opinions on them. The jury members assured that the audiobooks were both valid for the current study because they were suitable for the participants' linguistic level regarding the vocabulary used in them and their grammatical structure. Besides, they pointed out that the length of the texts of the audiobooks was reasonable and hence they would be acceptable by the participants. They also revealed that the quality of the narration sound of the audio recordings of the audiobooks was good as they were audible and comprehensible for the participants because they were delivered by native American speakers with normal and understandable pronunciation using reasonable speed.

The researcher also submitted the audiobooks to a pilot sample of 17 preparatory year students who did not take part with the participants in the present study in order to investigate their validity for the current study. The pilot sample revealed that the audiobooks were comprehensible and appropriate for their linguistic level because of their known vocabulary and proper grammar. They pointed out the familiarity of the topics of the audiobooks for them because they were of interest to them. They indicated that the printed versions of the audiobooks were readable, teachable and applicable for practicing listening and repeated listening while reading. They also assured that the quality of the audio recordings of the audiobooks was appropriate because they were all recorded with good quality at a proper speed which 
was audible and done with a normal delivery and clear accent. Therefore, these opinions of the pilot sample showed the validity of the audiobooks for the current study.

\section{- Sessions for Using the Audiobooks in Listening Comprehension}

The researcher designed sessions intended to be used in the training of the experimental group on the use of audiobooks for developing listening comprehension. The sessions included objectives, stages of listening, activities included in the listening stages, questions attached to listening stages and time required for doing the sessions. She validated these sessions through providing them to the jury members to reveal if they were applicable for the current study. The jury members assured that the sessions were valid for the current study because the objectives were proper, the activities in the listening stages were teachable and appropriate for the participants' age and linguistic level, the questions were suitable because they revolve around the listening topics and they were proper for the participants' linguistic level and the allocated time was appropriate for doing the activities.

\section{E. Treatment}

The researcher conducted the current study at the Preparatory Unit, Arar Branch, NBU, KSA as she taught English course to EFL preparatory year students there and realized that most of these students had weaknesses in listening comprehension. The National Commission for Academic Accreditation and Assessment (NCAAA) provided academic standards on listening skill at the preparatory year in KSA universities and assured the necessity of developing listening comprehension among EFL preparatory year students. Therefore, universities in KSA considered listening an essential skill in the context of learning EFL and stressed that EFL preparatory year students should master it. Thus, all KSA universities enclosed teaching listening in the English Language course provided to their preparatory year students. The English Language course taught to EFL preparatory year students at Arar Branch, NBU was comprised of teaching them grammar, listening, speaking, reading and writing. This course aimed at developing listening comprehension among EFL preparatory year students regarding defining, comprehending and conveying information in oral and written forms as they understood from the materials which they listened to through sources such as tape recordings, news on TV and radio, videos, and other spoken language which they might encounter in their daily activities. Furthermore, the English Language course given to EFL preparatory students at NBU included listening lessons which were applied through listening and repeated listening to recorded materials without doing while reading activities to what they listened.

The treatment in the current study based on using audiobooks in practicing listening and repeated listening. It lasted for 10 weeks with 3 hours for each week as required for the application of the sessions of the current study. The type of listening implemented in the audiobooks was academic listening which based on listening to short stories downloaded on CDs by the researcher from the Internet. The researcher taught the participants throughout all the sessions of the current study. The control group received their listening sessions during the same academic semester and lasted for the same duration of time as the experimental group. The difference between the experimental group and the control group was that each student in the experimental group individually did listening and repeated listening to a text while following listening by doing silent reading from a printed version of the text whereas each student in the control group only listened and repeated listening to the same text without following her listening by using silent reading to the printed version of the text. Moreover, the researcher gave each student in the experimental group a CD that included the audio recordings of the texts of the audiobooks whereas the control group did not receive any CDs as they did listening and repeated listening with the help of the researcher by using a classroom computer. The researcher also supplied the experimental group with printed versions of the written texts of the audiobooks to be used during the sessions of the current study in doing silent reading while doing listening and repeated listening whereas the control group did not receive these printed version. The researcher provided the control group with the same questions which she gave to the experimental group on the audiobooks. The experimental and the control groups did listening stages to the short stories from no. 1 to no. 8 that were included in "Half-Past Seven Stories" book from the beginning of the $1^{\text {st }}$ week till the end of the $5^{\text {th }}$ week. Besides, they did listening stages to the short stories from no. 9 to no. 16 which were comprised in the same book from the beginning of the $6^{\text {th }}$ week till the end of the $10^{\text {th }}$ week. A description of the listening stages in the current study is introduced in the following section.

The Pre Listening Stage: To prepare the experimental group to identify the topic of the listening activity, motivate them to listen carefully to the listening texts and help them know the purpose of doing this listening, the researcher introduced the topic of the listening texts to them. Besides, the researcher discussed with the experimental group some questions about the topic to stimulate their background knowledge about it. The researcher also gave the experimental group instructions on how to do the tasks of the listening stages and showed them the KWL chart which was adapted from Beers (2003) to be used during the while-listening stage and the post-listening stage. The researcher informed them that the activities of this chart were about mark my words, mark who and question mark. Then, the researcher trained them through showing them examples on how to do the listening stages required from them and how to fill out the KWL chart.

The While Listening Stage: The researcher gave time to each student in the experimental group to individually listen to a text and to follow this listening by doing silent reading to it from a printed version of the text. She also gave each student time to repeat listening and to follow this repeated listening by using silent reading to the same text from the printed version of the text. She gave each student with multiple choice questions and the KWL chart to individually answer the questions and to fill out the chart during doing the repeated listening step in order to check her 
comprehension of the text. The researcher helped the experimental group to make themselves into small groups of 4 students in each group to check their individual answers on the questions and the KWL chart with their small group. She observed and guided the experimental group throughout doing this stage to facilitate the procedures through giving them advice when needed.

The Post Listening Stage: The researcher discussed with the experimental group their answers on the KWL chart and asked them some open-ended questions on the text which they had listened and repeated listening to in order to check their comprehension of it. Each small group was given the opportunity to write together a summary of the listening text. Then, the researcher gave them feedback on their answers.

\section{RESULTS}

\section{A. Result of Hypothesis One}

The researcher used the t-test to explore the difference in the mean scores between the experimental group and the control group on the post LCT. The result revealed that the difference in the mean scores between the experimental group and the control group on the post LCT was statistically significant $(t=34.68, p<0.05)$. So, the $1^{\text {st }}$ hypothesis was accepted. Table (2) presented this result.

TABLE 2

THE T-VALUE OF THE DIFFERENCE IN THE MEAN SCORES BETWEEN THE EXPERIMENTAL GROUP AND THE CONTROL GROUP ON THE POST LCT

\begin{tabular}{l|l|l|l|l|l|l}
\hline Group & $\mathrm{N}$ & Mean & SD & DF & T & Sig. \\
\cline { 1 - 4 } Experimental & 44 & 23.32 & 1.95 & \multirow{2}{*}{86} & \multirow{2}{*}{34.68} & \\
\hline Control & 44 & 10.09 & 1.61 & & & \\
\hline
\end{tabular}

\section{B. Result of Hypothesis Two}

The researcher used the t-test to examine the difference in the mean scores of the experimental group between the pre and post LCT. The result indicated that the difference in the mean scores of the experimental group between the pre and post LCT was statistically significant $(t=30.26, p<0.05)$. Thus, the $2^{\text {nd }}$ hypothesis was accepted. Table (3) showed this result.

TABLE 3

THE T-VALUE OF THE DIFFERENCE IN THE MEAN SCORES OF THE EXPERIMENTAL GROUP BETWEEN THE PRE AND POST LCT

\begin{tabular}{l|l|l|l|l|l|l}
\hline Group & $\mathrm{N}$ & Mean & SD & DF & T & Sig. \\
\hline Pre Experimental & 44 & 10.59 & 2.08 & \multirow{2}{*}{43} & \multirow{2}{*}{30.26} & \multirow{2}{*}{0.000} \\
\hline Post Experimental & 44 & 23.32 & 1.95 & & & \\
\hline
\end{tabular}

\section{DISCUSSION}

The results in the current study revealed that the use of audiobooks significantly improved listening comprehension among the experimental group. In fact, the audiobooks implemented in the current study with the experimental group made a perfect environment for them to listen and read at the same time to interact with the content of the texts, gave them variety to comprehend the information given in the listening texts through individual activities and discussions together and with the researcher and thus led them to develop their listening comprehension. The development in listening comprehension among the experimental group on the post LCT might be because audiobooks enjoy having the features of characterization, theme, tone, setting and other important features of the text (Brown, 2002). And, because some audiobooks have the merit of using both female and male narrators, music, and sound effects in order to add to the realism of the text (Wolfson, 2008). Moreover, audiobooks are characterized by easy access and use by students and teachers and this facilitates acquiring, teaching, learning and development of listening. On the other hand, most audiobooks on the Internet are provided in PDF forms and can be easily downloaded on computers and printed into readable versions to be used in while reading activities.

The audiobooks used in the current study allowed the experimental group to listen as well as repeat listening while reading by using a printed version of the listening material. Repeated listening to the listening material proved to be useful in improving students' listening fluency (Nation \& Newton, 2009). Furthermore, the audiobooks used in the current study played an essential role in developing listening comprehension among the experimental group because an audiobook generally gives the natural tone of language delivered by a native speaker and hence it provides chances for learners to think about the real language and improve their listening comprehension. This means that audiobooks proved to be an effective tool for acquiring a FL and comprehending it as it is spoken. Consequently, audiobooks can be considered as a new technique which should be integrated into EFL curriculum to be applied by teachers in listening classrooms to develop listening comprehension among learners.

The current study's results are in agreement with the results of a study designed by Grover and Hannegan (2005). The findings in the present study also support the results of Kartal and Şimşek's (2011) study. These studies revealed that audiobooks are useful in developing reading comprehension and listening skills among learners. The researcher gave the experimental group a chance to discuss their opinions regarding their experience with using audiobooks in the 
treatment of the current study. All of the experimental group commented positively on using audiobooks in developing their listening comprehension. They indicated that they found out that audiobooks were helpful for improving their listening comprehension and they enjoyed using audiobooks for listening and reading at the same time. They also assured that audiobooks motivated them to read and listen to more books and hence they were interested in using audiobooks as a learning tool in the future and in using them to do listening assignments at out of classrooms activities. They revealed that they believed that audiobooks made them became more excited to like reading and listening and more enthusiasm for developing their listening comprehension. The opinions of the experimental group about the usefulness of using audiobooks for enhancing listening comprehension were in line with the responses of students in the study of O'Day (2002). They also regarded audiobooks as good tools which are helpful and effective in developing listening.

\section{CONCLUSION}

The researcher concluded from the results of the present study that audiobooks were useful in developing listening comprehension among EFL preparatory year students. Therefore, audiobooks should be applied in classroom listening sessions and in doing home assignments given by EFL instructors in order to enhance listening comprehension among EFL university students.

\section{A. Recommendations}

The researcher introduced these recommendations from the results of the current study:

- University instructors should be trained on the use of audiobooks in teaching of listening comprehension to EFL preparatory year students.

- Curriculum developers should enclose audiobooks for teaching listening comprehension to EFL preparatory year students.

- Suitable audiobooks for practicing listening comprehension should be available to EFL preparatory year students and their EFL instructors.

- University EFL instructors who teach at the preparatory year should allocate home assignments based on audiobooks use in addition to incorporating audiobooks into classroom practice.

\section{B. Suggestions for Further Research}

These studies were suggested for further research:

- A study which replicates the current study can be done with more EFL preparatory year students to obtain more generalizations of the results.

- A study can be conducted to explore the effectiveness of using audiobooks on reducing listening anxiety among EFL preparatory year students.

- A study can be carried out to examine the effect of using audiobooks on developing critical listening among EFL preparatory year students.

- A study can be conducted to explore the effectiveness of using audiobooks on improving fluent reading among EFL preparatory year students.

- Another study can be done to reveal the usefulness of audiobooks on improving pronunciation among EFL preparatory year students.

\section{REFERENCES}

[1] Alotaibi, N. (2014). The impact of digital audio listening on Saudi Arabian English Language learners' speaking and comprehension. M.A. thesis. The Graduate College of Bowling Green State University. https://etd.ohiolink.edu/pg_10?0::NO:10:P10_ETD_SUBID:91314 (accessed 1/2/2016).

[2] Anderson, R. (1922). Half-past seven stories. New York, NY: G.P. Putnam's Sons. http://etc.usf.edu/lit2go/93/half-past-sevenstories/ (accessed 13/1/2016).

[3] Batel, E. (2014). The effectiveness of video vs. written text in English comprehension and acquisition of ESL students. Arab World English Journal, 5(4), 326-335.

[4] Beers, K. (1998). Listen while you read. School Library Journal, 4(4), 30-35

[5] Beers, K. (2003). When kids can't read what teachers can do? Portsmouth, NH: Heinemann.

[6] Berne, J. (1995). How does varying pre-listening activities affect Second Language listening comprehension. Hispania, 78, 2 , 316-329.

[7] Berne, J. (2004). Listening comprehension strategies: A review of the literature. Foreign Language Annals, 37(4), $521-531$.

[8] Blake, Virgil L. P. (1990). Something new has been added: Aural literacy and libraries. In Virgil L. P. Blake and Rence Tjoumas (Eds.) Information literacies for the twenty-first century (pp. 203-218). Boston: G. K. Hall \& Co.

[9] Blum, I., Koskinen, P., Tennant, N., Parker, E., Straub, M., \& Curry, C. (1995). Using audiotaped books to extend classroom literacy instruction into the homes of second language learners. Journal of Reading Behavior, 27(4), 535-563.

[10] Brown, J. (2002). Audio books in the classroom: Bridging between language arts and social studies. The ALAN Review, 29(3), $58-59$.

[11] Brown, J., \& Fisher, P. (2006). Balanced literacy: One middle school's experience. Principal Leadership, 7(1), 38-40. 
[12] Clement, J. (2007). The impact of teaching explicit listening strategies to adult intermediate- and advanced-level ESL university students. Retrieved from ProQuest Dissertations and Theses. (UMI No. 3253098).

[13] Downs, L. (2008). Listening skills training. USA: ASTD Press.

[14] Elkhafaifi, H. (2005). The effect of pre-listening activities on listening comprehension in Arabic learners. Foreign Language Annuals, 38(4) 505-513. http://dx.doi.org/10.1111/j.1944-9720.2005.tb02517.x.

[15] Field, J. (1998). Skills and strategies: Towards a new methodology for listening. ELT Journal, 52(2), 110-18.

[16] Getahchew, B. (2002). Teaching language skills. A.A: Educational Media Agency.

[17] Gilakjani, A., \& Ahmadi, A. (2011). A study of factors affecting EFL learners' English listening comprehension and the strategies for improvement. Journal of Language Teaching and Research, 2(5), 977-988.

[18] Golonka, E., Bowles, A., Frank, V., Richardson, D., \& Freynik, S. (2014). Technologies for foreign language learning: A review of technology types and their effectiveness. Computer Assisted Language Learning, 27(1), 70-105.

[19] Graham, S. (2006). Listening comprehension: The learners' perspective. System, 34(2), 165-182.

[20] Grover, S., \& Hannegan, L. (2005). Not just for listening: Integrating audiobooks into the curriculum. Book links, 14(5), 16-19.

[21] Hamdan, M. (2015). The perceptions of Saudi EFL English-major students of the impact of video materials on the improvement the listening skill. International Journal of Linguistics, 7(1), 111-128.

[22] Harris, D. (2001). An inquiry into the influence of taped books on the oral reading performance of struggling third-grade readers. Retrieved from ProQuest Dissertations and Theses. (UMI No. 304700784)

[23] Hett, K. (2012). Technology-supported literacy in the classroom: Using audiobooks and digital storytelling to enhance literacy instruction. Illinois Reading Council Journal, 40(3), 3-13.

[24] Jacobs, T. (2006). Teaching with audiobooks. Article Alley. www.articlealley.com (accessed 11/1/2016).

[25] Kartal, G., \& Şimşek, G. (2011). The use of audiobooks in EFL classes to improve reading and listening skills. 2nd International Conference on New Trends in Education and their Implications 27-29 April, 2011 Antalya-Turkey, (pp. 15641569). iconte.org/FileUpload/ks59689/File/276._galip_kartal.pdf (accessed 13/1/2016).

[26] Kao, C. (2006). EFL listening comprehension strategies used by students at the Southern Taiwan University of technology. Retrieved from ProQuest Dissertations and Theses. (UMI No.3255093)

[27] Kintsch, W., \& Kintsch, E. (2005). Comprehension. In: S. G. Paris and S. A. Stahl (Eds.), Current issues in reading comprehension and assessment (pp. 71-92). Mahwah, NJ: Lawrence Erlbaum Associates

[28] Koskinen, P., Blum, I., Bisson, S., Phillips, S., Creamer, T., \& Baker, T. (2000). Book access, shared reading, and audio models: The effects of supporting the literacy learning of linguistically diverse students in school and at home. Journal of Educational Psychology, 92(1), 23-36.

[29] Liu, Y. (2009). The utilization of listening strategies in the development of listening comprehension among skilled and lessskilled non-native English speakers at the college level. Retrieved from ProQuest Dissertations and Theses. (UMI No. 3400780)

[30] Marchionda, D. (2001). A bridge to literacy: Creating lifelong readers through audiobooks. Audio File Magazine, 10(2), 19-21.

[31] Mendelsohn, D. (2001). Listening comprehension: We've come a long way, but... Contact, 27(2), 33-40.

[32] Nalder, S., \& Elley, W. (2003). Using audio-taped read along stories with low-progress readers. rainbowreading.org.nz/wp.../08/audio-taped-read-along-stories.pdf (accessed 3/1/2016).

[33] Nation, I.S.P. \& Newton, J. (2009). Teaching ESL/EFL listening and speaking. Routledge: Taylor \& Francis.

[34] O'Day, P. (2002). Reading while listening: Increasing access to print through the use of audio books. Retrieved from ProQuest Dissertations and Theses. (UMI No. 493978518).

[35] Oxford, R. (1993). Research update on teaching L2 listening. System, 21(2), 205-211.

[36] Rahimi, A. (2012). On the role of strategy use and strategy instruction in listening comprehension. Journal of Language Teaching and Research, 3(3), 550-559. http://dx.doi.org/10.4304/jltr.3.3.550-559.

[37] Richards, J., \& Renandya, W. (2002). Methodology in language-An anthology of current research practice. New York: Cambridge University Press.

[38] Rost, M. (2002). Listening tasks and language acquisition. JALT 2002 AT SHIZUOKA, conference proceedings. University of California, Berkeley; 18-28. http://jalt-publications.org/archive/proceedings/2002/018.pdf (accessed 7/1/2016).

[39] Rubery, M. (2011). Audiobooks, literature, and sound studies. Routledge: Taylor \& Francis.

[40] Saka, Z. (2015). The effectiveness of audiobooks on pronunciation skills of EFL learners at different proficiency levels. MA thesis. Ankara: Bilkent University. www.thesis.bilkent.edu.tr/0006898.pdf (accessed 9/1/2016).

[41] Serafini, F. (2004). Audiobooks \& literacy: An educator's guide to utilizing audiobooks in the classroom. New York: Random House Inc.

[42] Shany, M., \& Biemiller, A. (1995). Assisted reading practice: Effects on performance for poor readers in grades 3 and 4. Reading Research Quarterly, 30, 382-395.

[43] Stone-Harris, S. (2008). The benefit of utilizing audiobooks with students who are struggling readers. Retrieved from ProQuest Dissertations and Theses. (UMI No.304389547)

[44] Tagninezhad, A, Khalifah, A., Nabizadeh, A. \& Shahab, S. (2015). Examining the influence of using audiobooks on the improvement of sound recognition and sound production of Iranian EFL learners. International Journal of Languages' Education and Teaching, 3(3), 28-42.

[45] Taguchi, E., Takayasu-Maass, M., \& Gorsuch, G. (2004). Developing reading fluency in EFL: How assisted repeated reading and extensive reading affect fluency development. Reading in a Foreign Language, 16(2), 70-96.

[46] Taylor, J., \& Moore, P. (2001). Prepare and Practice for the computer-based TOEFL test. Newbury: Express Publishing.

[47] Thooft, N. (2011). The Effect of audio books on reading comprehension and motivation. Retrieved from ProQuest Dissertations and Theses. (UMI No.1507106).

[48] Türker, S. (2010). The effectiveness of audio books on the reading comprehension of selected texts by university EFL students at different proficiency levels. MA. Thesis. Bilkent, University, Ankara, Turkey. www.thesis.bilkent.edu.tr/0003964.pdf (accessed 11/1/2016). 
[49] Vandergrift, L. (1999). Facilitating second language listening comprehension: Acquiring successful strategies. ELT journal, 53(3), 168-176. http://203.72.145.166/ELT/files/53-3-3.pdf (accessed 11/1/2016).

[50] Vandergrift, L. (2003). Orchestrating strategy use: Toward a model of the skilled second language listener. Language Learning, 53, 463-496. http://dx.doi.org/10.1111/1467-9922.0023

[51] Vandergrift, L. (2007). Recent developments in second and foreign language listening comprehension research. Language Teaching, 40(3), 191-210. http://dx.doi.org/10.1017/S0261444807004338.

[52] White, G. (2006). Teaching listening: Time for a change in methodology. In E Usó-Juan, \& A. Martínez-Flor. (Eds), Studies on Second Language Acquisition: Current trends in the development and teaching of the four language skills (pp. 111-135), Berlin: Walter de Gruyter.

[53] Wilson, J. (2008). How to teach listening. Malaysia: Pearson Education Limited.

[54] Wolfson, G. (2008). Using audiobooks to meet the needs of adolescent readers. American Secondary Education, 36(2), 105-117.

[55] Woodall, B. (2010). Simultaneous listening and reading in ESL: Helping second language learners read (and enjoy reading) more efficiently. TESOL Journal, 1, 2, 186-205.

Manal M. Khodary is from Luxor, Egypt. She is an associate professor of TEFL Instruction at Curriculum and Instruction Department, Ismailia Faculty of Education in, Suez Canal University, Egypt. She previously worked as an associate professor of TEFL at Arar Faculty of Education and Arts, Northern Border University, Kingdom of Saudi Arabia. She published a number of articles in international refereed journals and conferences in the area of TEFL, e-Learning, integration of digital technologies into EFL classrooms and Curriculum design. She participated in many conferences and workshops. She supervised some M. Ed. Theses and Ph.D. Dissertations. 